\title{
Influence of the contact time of the preflush fluid with the filter cake on the effectiveness of the purification of the annular space
}

In the process of drilling wells, tightness in the annular space between casing string and beyond is of particular importance. In order to eliminate undesirable gas migration due to lack of tightness, lowered casing string should be sealed by filling the annular space with cement slurry. During the pumping of cement slurry, drilling mud is removed from the annular space. However, cement slurry pumped directly after the mud, cannot sufficient remove residues from the mud. In order to properly seal the borehole with cement slurry, which after binding is designed to prevent the flow of gas, it is necessary to clean the annular space from filter cake by pumping the preflush fluid, and then completely removing the mud by spacer fluid and cement slurry. Fulfilling these conditions and obtaining a properly cleaned annular space prior to cementation can help improve the sealing and to some extent eliminate the possibility of undesirable gas migration at the contact of the cement sheath with the contact surfaces (casing string and rock formation). Taking into account the problem of improving the cleaning of the annular space and related issues, the laboratory tests have been carried out to determine the effect of the contact time of the preflushes on the purification of the annular space. During conducting the laboratory tests used the simplest type of preflush fluid, which was water. Such selection was conditioned by the necessity to demonstrate the effect of contact time on the efficiency of cleaning the annular space, excluding the physico-chemical action of the surfactant used in the preflush liquid. In order to pick up changes, control samples were also prepared on which no filter cake was produced. Laboratory tests of the effect of the contact time of the preflush fluid on the purification of the annular space were conducted by determining the adhesion of the cement sheath to the rock formation, from which the previously produced filter cake was removed.

Key words: contact time of the preflush fluid, wash fluid, preflush fluid, cleaning of the annular space.

\section{Wpływ czasu kontaktu cieczy przemywającej z osadem płuczkowym na skuteczność oczyszczenia przestrzeni pierścieniowej}

W procesie wiercenia otworów wiertniczych szczególne znaczenie odgrywa zapewnienie szczelności w przestrzeni pierścieniowej pomiędzy kolumnami rur oraz poza nimi. W celu wyeliminowania m.in. niepożądanych zjawisk migracji gazu na skutek braku szczelności należy zapuszczoną kolumnę rur okładzinowych uszczelnić wypełniając przestrzeń pierścieniową lub pozarurową zaczynem cementowym. W trakcie tłoczenia zaczynu cementowego z przestrzeni pierścieniowej wypierana jest płuczka. Jednak tłoczony zaczyn cementowy nie jest w stanie dostatecznie dobrze usunąć pozostałości po płuczce. W celu dobrego uszczelnienia otworu zaczynem, który po związaniu ma za zadanie uniemożliwić przepływ gazu konieczne jest dokładne oczyszczenie przestrzeni pierścieniowej z osadu płuczkowego poprzez przetłoczenie cieczy przemywającej, a następnie całkowite wyparcie płuczki przez ciecz buforową i zaczyn cementowy. Spełnienie tych warunków i uzyskanie odpowiednio oczyszczonej przestrzeni pierścieniowej przed zabiegiem cementowania może przyczynić się do poprawy uszczelnienia i w pewnym stopniu wyeliminować możliwość zachodzenia niepożądanego zjawiska migracji gazu na kontakcie płaszcza cementowego z powierzchniami styku (rurą okładzinową i formacją skalną). Biorąc pod uwagę problem poprawy oczyszczenia przestrzeni pierścieniowej i związane z nim zagadnienia, przeprowadzone zostały badania laboratoryjne pod kątem określenia wpływu czasu kontaktu cieczy przemywającej na poprawę oczyszczenia przestrzeni pierścieniowej. Podczas realizacji pracy wykorzystano najprostszy rodzaj cieczy przemywającej, którą była woda. Wybór taki uwarunkowano koniecznością wykazania wpływu czasu kontaktu cieczy przemywającej na skuteczność oczyszczenia przestrzeni pierścieniowej. Pominięto działanie fizykochemiczne użytych środków powierzchniowo czynnych. W celu wychwycenia zmian efektywności oczyszczania sporządzono również próbkę kontrolną rdzenia skalnego, na której nie wytwarzano osadu płuczkowego. Badania wpływu czasu kontaktu cieczy przemywającej na oczyszczenie przestrzeni pierścieniowej prowadzone 
były poprzez pomiar przyczepności płaszcza cementowego do formacji skalnej, z której usuwano wytworzony wcześniej osad płuczkowy. Na podstawie tego pomiaru określano skuteczność usunięcia osadu płuczkowego.

Słowa kluczowe: czas kontaktu cieczy przemywającej, przemywki, ciecze przemywające, oczyszczenie przestrzeni pierścieniowej.

\section{Introduction}

During the cementation procedure, a sequence of fluids is injected into the annular space in order to displace the drilling mud and prepare the annular space or space outside the casing for filling with cement slurry. After drilling through a particular interval, a purification process is carried out in the borehole in order to remove the drilled material. Then, the drilling string is removed from the borehole and the circulation is interrupted, after which geophysical measurements are carried out in the borehole and the casings are lowered and the circulation is resumed $[5,7,8]$. After the casings have been lowered and the drilling mud treatment has been completed, preflush fluids are injected into the borehole. They allow for proper preparation of the annular space prior to cementation. Preflush fluids should meet the following requirements [2-4]:

- the need to hydrate the casing string and rock formation to improve cement slurry setting,

- the necessity of injecting fluids in the turbulent regime to improve the effectiveness of drilling mud removal but without causing fractures in the formation (which may happen if the pumping rate and thus the bottom pressure in the borehole increases too much),

- ensure that there is sufficient contact time of the preflush fluids in the annular space or space outside the casing in order to achieve the required removal of the drilling mud and proper cleaning of the filter cake from the borehole walls,

- ensure they are easily pumped out by the spacer and cement slurry.

The issue of improvement of borehole annular space cleaning prior to cementation is a complex process. Appropriate cleaning of the annular space prior to the cementation process contributes to obtaining the required tightness on the contact between the rock formation, the cement sheath and the casings and thus helps eliminate the gas migration or exhalation after the cementation $[6,7]$. Proper cleaning of the annular space and sealing of the casing string also ensures long-term borehole exploitation by minimising the effect of corrosive environment on the casing string in aggressive conditions [9-11]. The issue of annular space cleaning includes aspects such as the rheology of drilling fluids, fluid mechanics (fluid flow in the annular space), the action of chemicals, surface active agent, surfactants and chemical additives during the hydration and setting of the cement slurry.
It should be noted that despite significant progress in the development of casing string sealing techniques and technologies, unsuccessful cementation processes are still observed. As already mentioned, the effective sealing of the casing strings undoubtedly depends on the proper cementation of individual casing strings in accordance with the requirements. However, this is just one of several requirements of the effective borehole sealing. It has been concluded on the basis of experiments that the quality and quantity of the filter cake deposited on the wall has a significant influence on the effectiveness of the sealing of the casing string $[12,14,15]$. Therefore, it is necessary to analyse the problem of annular space cleaning and the preflush fluid formulas developed specifically for given geological and technical conditions. However, the composition and effect of the preflush fluid on the removal of the filter cake are just one part of the problem, and the other part is the pumping regime used for these fluids. As we know, preflush fluids are described using the Newtonian fluid model, which causes dispersion of the drilling mud. Due to the low viscosity of preflush fluids, they are particularly useful for pumping in turbulent flow regimes. However, such flow characteristics require high pumping rates, and this, in turn, may be problematic for weakly consolidated geological structures. Pumping preflush fluids at high pumping rates in order to preserve the turbulent flow can have an adverse effect on the fracturing of the borehole zone, which should be taken into account when selecting the preflush fluid pumping regimes. However, in order to effectively remove the filter cake residues, it is essential to maintain the above-mentioned turbulent flow, which does not guarantee that the filter cake will be removed well. Therefore, there is a need to manipulate another variable influencing the effectiveness of the filter cake removal, i.e. the preflush fluid contact time $[1,13]$.

According to the Cementation Instructions ${ }^{1}$, the preflush fluid contact time should be within 6-10 minutes for a turbulent flow (10 minutes as standard), depending on the type of drilling mud and the required time of contact with the rock. Other sources recommend 4,5 or 8 minutes [3, 12]. It should be noted that the optimal contact time will depend on the pumping

${ }^{1}$ Borehole Cementation Instructions - internal document of Serwis Cementacyjny. 
rate of a given preflush fluid, its characteristics regarding the removal of a particular cake, the type of produced filter cake, borehole conditions (temperature and pressure) and many other parameters. Therefore, an improvement in the annular space cleaning depends not only on the appropriately selected contact time of the fluid and the space but also on the application of optimal pumping regimes and the proper selection of composition and properties of the preflush fluid. Due to the fact that literature provides only partial information on the influence of the contact time of the preflush fluid on the effectiveness of the filter cake removal from the annular space, this issue is discussed later in this publication.

\section{Research procedure}

The tests to determine the influence of the contact time of the preflush fluid with the filter cake on the effectiveness of the annular space cleaning were performed in the INiG - PIB Sealing Slurry Laboratory based on standards: PN-85/G-02320 Cements and cement slurries for cementation in boreholes; PN-EN 10426-2 Oil and gas industry. Cements and materials for well cementing. Part 2: Testing of well cements and API SPEC 10 Specification for materials and testing for well cements.

The study cycle presented in this publication consisted in demonstrating the influence of the contact time of the preflush fluid with the filter cake on the effectiveness of its removal. Tests were performed using water as the preflush fluid. A device has been designed in $\mathrm{INiG}$ - PIB for the performance of the test work. The device enables pumping of a sequence of drilling fluids in a closed circuit (a drilling fluid flow simulator - photo 1 ). The testing was performed for specific contact times of the preflush fluid and the rock at a constant pumping rate. The fluid contact times were 4, 6, 8 and 10 minutes, respectively. In the course of the research, cylindrical sandstone specimens with an outside diameter of $25 \mathrm{~mm}$ and a length of $60 \mathrm{~mm}$ were used (photo 2). The cores were placed on

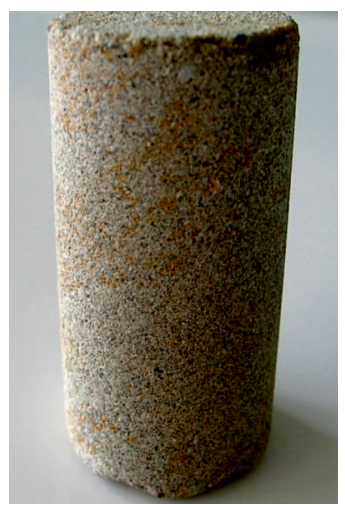

Photo 2. Core cut out of a sandstone specimen

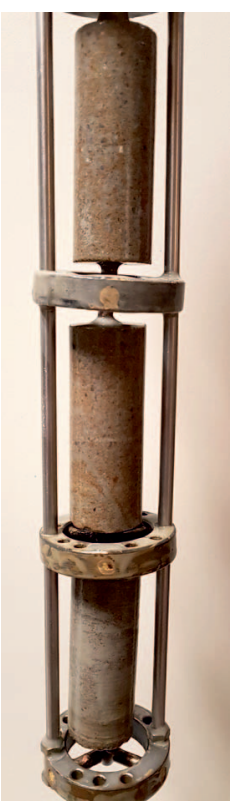

Photo 3. Sandstone cores mounted on a tripod

a custom-built tripod (photo 3, Fig. 1) mounted inside a plastic pipe (photo 4) in which the flow of drilling fluids (drilling mud, preflush fluid) occurred. This system simulated the annular space of a borehole.

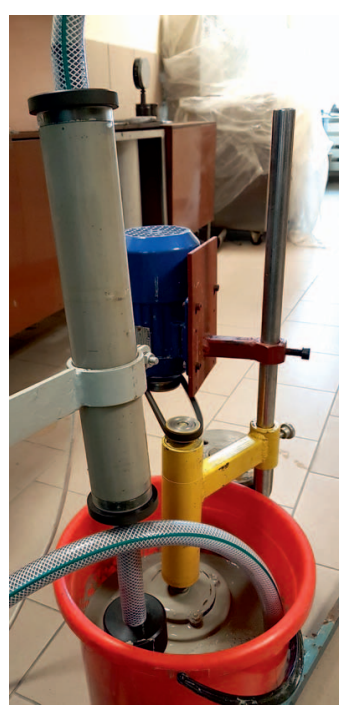

Photo 1. Borehole drilling fluid flow simulator (the device is in the course of pumping fluids)

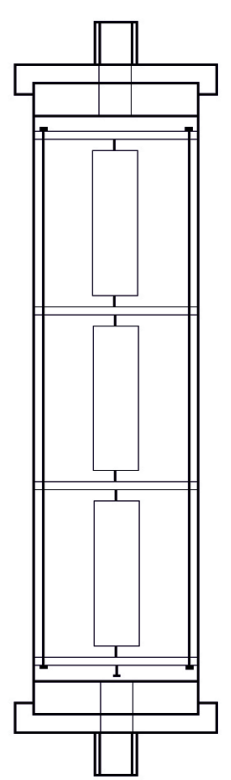

Fig. 1. Diagram of the sandstone cores placed on a tripod inside the plastic pipe

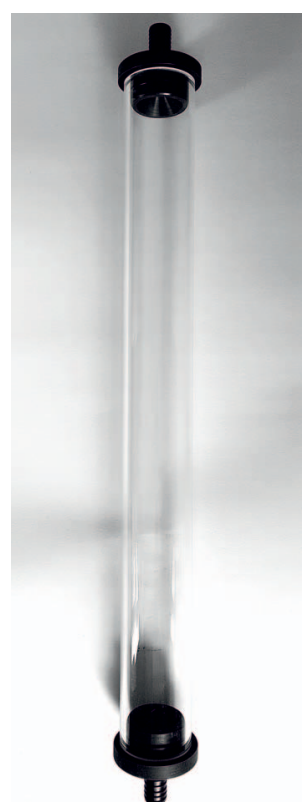

Photo 4. View of the plastic pipe together with sealants, in which the drilling fluid inlet and outlet have been fixed 
The research work began with the formation of filter cake from the drilling mud on the sandstone cores (photo 2). The cake was produced by the flow of the drilling mud in the simulated annular space and by washing three cores placed in the device with this drilling mud for 1 hour (photo 5). The drilling mud pumping rate was determined on the basis of preliminary tests and observations carried out during tests preparing the core specimens for testing.

A polymer-potassium drilling mud was used for the production of the filter cake. It was considered more appropriate to use a borehole drilling mud which contained impurities from the drilled layers than to prepare it under laboratory conditions.

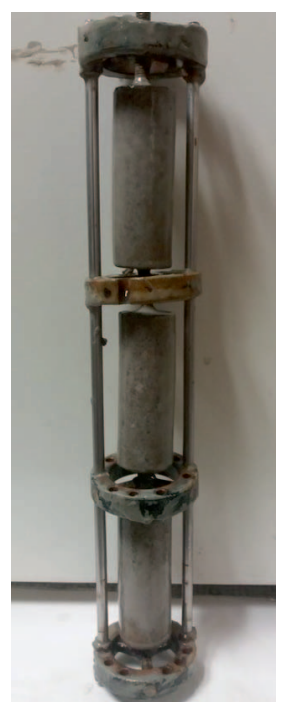

Photo 6. Contact time $4 \mathrm{~min}$ at the pumping rate of $11.2[1 / \mathrm{min}]$

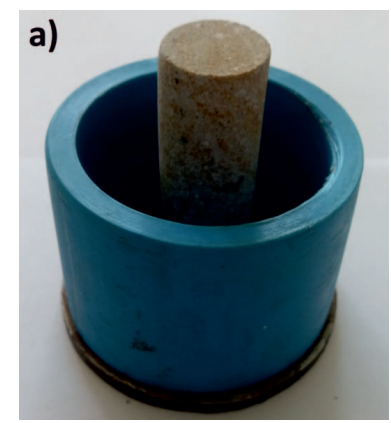

Photo 10. A core specimen prepared for filling with cement slurry

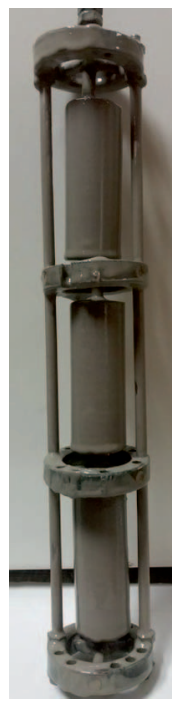

Photo 5. Cores with a filter cake (after washing with drilling mud)

In order to obtain reliable results, a drilling mud from borehole $\mathrm{P}-2 \mathrm{~K}$ was chosen in order to obtain a cake that is more difficult to remove than, for example, a non-clay mud. The cores were washed for 4, 6, 8 and 10 minutes after the formation of the filter cake. During the tests, the constant preflush fluid pumping rate of $11.2 \mathrm{l} / \mathrm{min}$ was assumed. This choice was determined by the flow of the fluid around the turbulent flow regime with a Re number of more than 3000. Photos 6 to 9 show the visual effect of the removal of the filter cake from the rock formation depending on the contact time of the preflush fluid at a constant fluid pumping rate.

In accordance with the adopted methodology, a test based on the determination of the adhesion on the contact between the bound cement and the rock formation was used as the indicator to enable the determination of the effectiveness of the removal of the filter cake by the pumped preflush fluid. For this purpose, sandstone core specimens with the filter cake were placed in a mould (photo 10) and flooded with cement slurry (photo 11) after having been washed with the preflush fluid for a specified time. After the specified hydration time, which

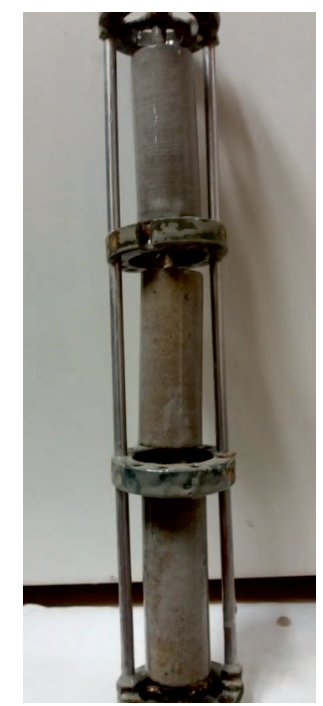

Photo 8 . Contact time $8 \mathrm{~min}$ at the pumping rate of $11.2[1 / \mathrm{min}]$

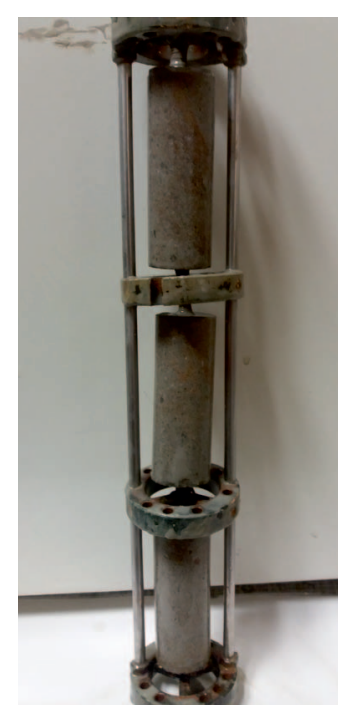

Photo 9. Contact time $10 \mathrm{~min}$ at the pumping rate of $11.2[1 / \mathrm{min}]$

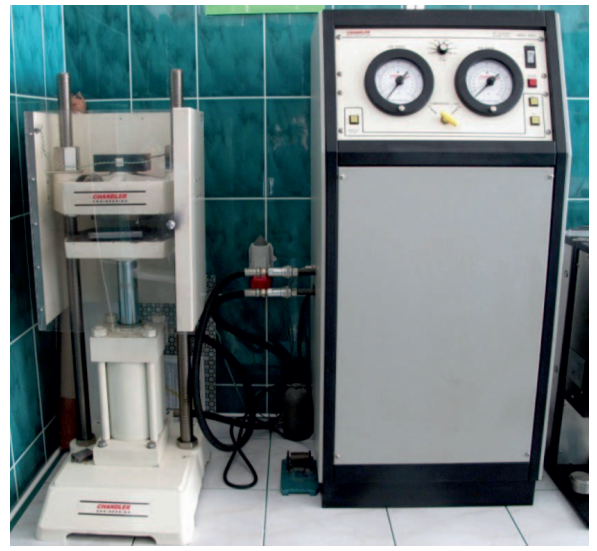

Photo 12. Testing machine 
was 48 hours, a test of the adhesion on the contact between the bound cement and the rock core was performed. To determine the adhesion, the specimens were placed between two plates of a testing machine (photo 12) measuring the breaking force for the adhesion on the contact between the bound cement and the rock under a load applied on the specimen.

After each measurement of the force required to break the adhesion between the bound cement and the rock, the adhesion expressed in MPa was calculated according to formula (1):

$$
\sigma_{p}=\frac{P}{S} \cdot 10^{-3}[\mathrm{MPa}]
$$

where:

$P$ - the pressure force causing the breaking of bound cement and rock connection $[\mathrm{kN}]$,

$s$ - the contact surface of the rock specimen with the bound cement $\left[\mathrm{m}^{2}\right]$.

The pressure force $(P)$ was read directly from the testing machine indicator, whereas the contact surface of the rock and bound cement resulted from the surface area of the test core and the external height of the cement slurry in the mould. Figure 2 presents the dimensions needed to calculate the contact surface area between the rock and bound cement.

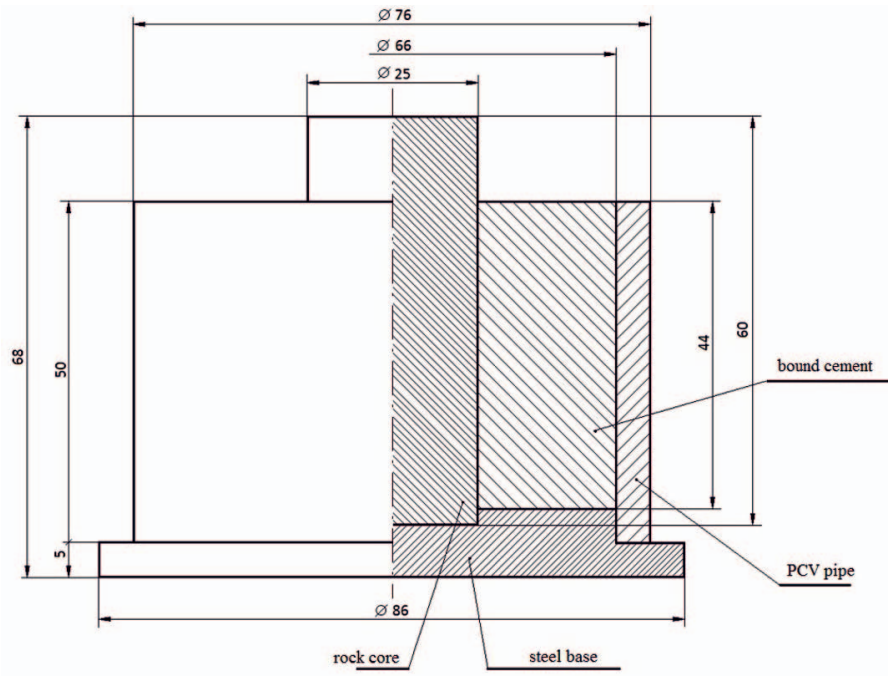

Fig. 2. Half section of a mould with the specimen core inside

Table 1. Base adhesion on the contact between the bound cement and the rock

\begin{tabular}{|l|c|c|}
\cline { 2 - 3 } \multicolumn{1}{c|}{} & $\begin{array}{c}\text { Adhesion } \\
\text { breaking force } \\
{[\mathrm{kN}]}\end{array}$ & $\begin{array}{c}\text { Adhesion on the contact between } \\
\text { the bound cement and the rock } \\
{[\mathrm{MPa}]}\end{array}$ \\
\hline $\begin{array}{l}\text { Maximum } \\
\text { base adhesion }\end{array}$ & 8.2 & 2.37 \\
\hline $\begin{array}{l}\text { Minimum } \\
\text { base adhesion }\end{array}$ & 2.1 & 0.61 \\
\hline
\end{tabular}

Table 2. The formula and parameters of the cement slurry used in the testing of the adhesion on the contact between bound cement and the rock

\begin{tabular}{|c|c|c|c|c|c|c|c|c|c|c|c|}
\hline \multirow{2}{*}{\multicolumn{3}{|c|}{ Slurry composition }} & \multicolumn{9}{|c|}{ Slurry parameters } \\
\hline & & & \multicolumn{7}{|c|}{ Density $\left[\mathrm{g} / \mathrm{cm}^{3}\right]$} & \multicolumn{2}{|c|}{1.78} \\
\hline \multicolumn{2}{|l|}{ Water } & $\mathrm{w} / \mathrm{c}=0.45$ & \multicolumn{7}{|c|}{ Fluidity } & \multicolumn{2}{|c|}{240} \\
\hline \multicolumn{2}{|c|}{ Anti-foam agent } & $0.5 \%$ & \multicolumn{7}{|c|}{ Water loss [\%] } & \multicolumn{2}{|c|}{0.0} \\
\hline \multicolumn{2}{|c|}{ Thinning agent } & $0.2 \%$ & \multicolumn{7}{|c|}{ Plastic viscosity $[\mathrm{mPa} \cdot \mathrm{s}]$} & \multicolumn{2}{|c|}{91.5} \\
\hline \multicolumn{2}{|c|}{ Anti-filtration agent } & $0.2 \%$ & \multicolumn{7}{|c|}{ Flow limit $[\mathrm{Pa}]$} & \multicolumn{2}{|c|}{6.48} \\
\hline \multicolumn{2}{|c|}{ Calcium chloride } & $4.0 \%$ & \multicolumn{7}{|c|}{ Structural strength $[\mathrm{Pa}]$} & \multicolumn{2}{|c|}{2.88} \\
\hline \multicolumn{2}{|c|}{ Potassium chloride $\left(\right.$ bwow $\left.^{2}\right)$} & $3.0 \%$ & \multicolumn{7}{|c|}{ Filtration $\left[\mathrm{cm}^{3} / 30 \mathrm{~min}\right]$} & \multicolumn{2}{|c|}{36.0} \\
\hline \multicolumn{2}{|l|}{ Latex } & $10.0 \%$ & \multirow{2}{*}{\multicolumn{4}{|c|}{ Thickening time at a temp. of $25^{\circ} \mathrm{C}$}} & \multicolumn{3}{|c|}{ Value $30 \mathrm{Bc}$ [h:min] } & \multicolumn{2}{|c|}{$2: 55$} \\
\hline \multicolumn{2}{|c|}{ Latex stabilisation } & $1.0 \%$ & & & & & \multicolumn{3}{|c|}{ Value $100 \mathrm{Bc}^{3}$ [h:min] } & \multicolumn{2}{|c|}{$3: 32$} \\
\hline \multicolumn{2}{|c|}{ Microcement } & $10.0 \%$ & \multirow{2}{*}{\multicolumn{4}{|c|}{ Setting time at a temp. of $20^{\circ} \mathrm{C}$}} & \multicolumn{3}{|c|}{ beginning [h:min] } & \multicolumn{2}{|c|}{$4: 45$} \\
\hline \multicolumn{2}{|c|}{ CEM I 32.5R cement } & $100 \%$ & & & & & \multicolumn{3}{|c|}{ end [h:min] } & \multicolumn{2}{|c|}{$5: 35$} \\
\hline Swelling a & ent & $0.3 \%$ & Com & $\operatorname{sion} \mathrm{s}$ & th afte & $3 \mathrm{~h}[\mathrm{MPa}]$ & 10 & & & & \\
\hline Rheological & Rpm & 600 & 300 & 200 & 100 & 60 & 30 & 6 & 3 & $10 "$ & $10^{\prime}$ \\
\hline $\begin{array}{l}\text { parameters at the } \\
\text { temp: }\left[20^{\circ} \mathrm{C}\right]\end{array}$ & $\begin{array}{l}\text { Reading in } \\
\text { [Fann units }\end{array}$ & 187 & 105 & 74 & 44 & 27 & 17 & 6 & 4 & 6 & 16 \\
\hline
\end{tabular}

Quantities of all the agents except for potassium chloride are given as a percentage in relation to the amount of cement.

${ }^{2}$ bwow - by weight of water - in relation to the volume of mixing water.

${ }^{3} \mathrm{Bc}-\mathrm{a}$ consistency unit of cement slurry thickening during a measurement in the consistency meter. 
These are:

- core diameter $(d)=25 \mathrm{~mm}=0.025 \mathrm{~m}$,

- the height of the cemented part of the core $(h)=44 \mathrm{~mm}$ $=0.044 \mathrm{~m}$.

$$
\begin{gathered}
s=\pi \cdot d \cdot h \\
s=\pi \cdot 0.025 \cdot 0.044=0.003456\left[\mathrm{~m}^{2}\right]
\end{gathered}
$$

The adhesion on the contact between bound cement and the rock $\sigma_{p}$ was determined using formula [4]:

$$
\sigma_{p}=\frac{P}{0.003456} \cdot 10^{-3}=\frac{P}{3.456}[\mathrm{MPa}]
$$

In order to determine the base (maximum and minimum) adhesion, an adhesion test was also carried out on the "clean" core without a filter cake and on the core with a filter cake but excluding the cake removal stage. Further test results were compared against these values. All cores were flooded with cement slurry with the same composition and the parameters as shown in Table 2. This was the slurry composition most commonly used to seal the casing strings at a temperature of approx. $25^{\circ} \mathrm{C}$.

Values within the range of $1.01 \div 1.67 \mathrm{MPa}$ were obtained during the test of the adhesion on the contact between the bound cement and the rock core cleaned of the preformed filter cake. When comparing the obtained results to the minimum base adhesion of $0.61 \mathrm{MPa}$, an increase in the adhesion values in the range from $66 \%$ (for the contact time of 4 minutes) to $174 \%$ (for the contact time of 10 minutes) was achieved - Table 3. On the other hand, when correlating the obtained adhesion values with the maximum base adhesion of $2.37 \mathrm{MPa}$ (Table 1), the obtained results were lower by values ranging from $57 \%$ for 4-minute washing to $29 \%$ for the 10 -minute contact time of the preflush fluid pumped at the rate of $11.2 \mathrm{l} / \mathrm{min}$. Table 3 shows the obtained values together with the comparison against the maximum and minimum base adhesion values and Figure 3 shows the graphical summary of the results of the effectiveness of the filter cake removal in relation to the contact time

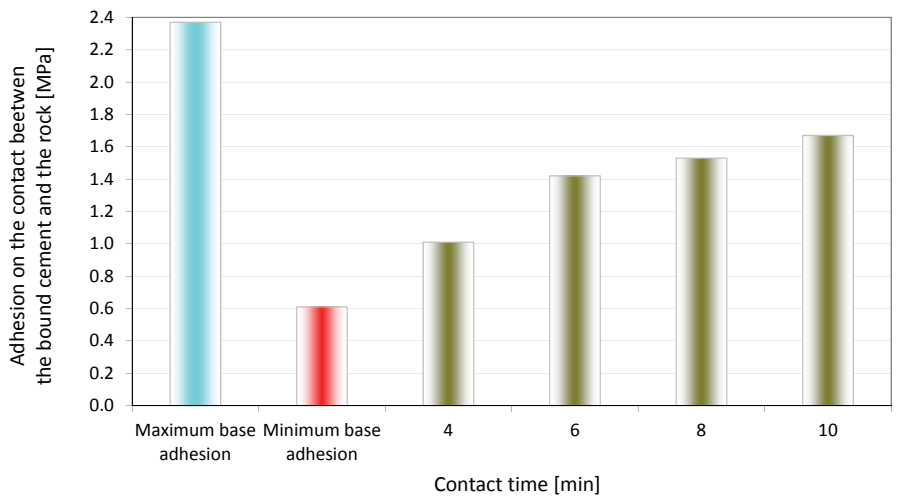

Fig. 3. The adhesion on the contact between the bound cement and the rock for different contact times of the preflush fluid at the pumping rate of $11.2 \mathrm{l} / \mathrm{min}$

of the preflush fluid and a comparison with the maximum and minimum base values.

During the tests, a filter cake formed on the surface of the rock (the reference specimen), which was then removed by the preflush fluid (water as a standard). The tests carried out in this part of the study were aimed at representing the flow of the fluid from the borehole conditions to laboratory conditions. When determining the influence of the contact time of the preflush fluid with the filter cake on the effectiveness of the annular space cleaning, adhesion tests were carried out on the contact between the bound cement and the rock core cleaned of the formed filter cake.

After an analysis of the obtained results, it was found that there was an increase in adhesion on the contact of the bound cement and the rock formation with an increase in the contact time of the preflush fluid and the cleaned annular space, and thus there was an improvement in the removal of filter cake from the rock formation.

The contact time significantly affects the effectiveness of the filter cake removal from the rock formation. A $66 \%$ increase in adhesion was achieved with a minimum contact time of 4 minutes for the preflush fluid. However, an increase in the contact time by additional 2 minutes (the contact time of 6 minutes) resulted in a $100 \%$ increase in adhesion in relation to the value obtained

Table 3. Adhesion between the bound cement and the rock for different contact times of the preflush fluid and the pumping rate of $11.2 \mathrm{l} / \mathrm{min}$

\begin{tabular}{|c|c|c|c|c|}
\hline Contact time $[\mathrm{min}]$ & $\begin{array}{c}\text { Adhesion } \\
\text { breaking force } \\
{[\mathrm{kN}]}\end{array}$ & $\begin{array}{c}\text { Adhesion on the contact between } \\
\text { the bound cement and the rock } \\
{[\mathrm{MPa}]}\end{array}$ & $\begin{array}{c}\text { Percentage change in the } \\
\text { adhesion in relation to the } \\
\text { maximum base adhesion }\end{array}$ & $\begin{array}{c}\text { Percentage change in the } \\
\text { adhesion compared to } \\
\text { thinimum base adhesion }\end{array}$ \\
\hline 4 & 3.5 & 1.01 & $\downarrow \mathbf{5 7 \%}$ & $\uparrow \mathbf{6 6 \%}$ \\
\hline 6 & 4.9 & 1.42 & $\downarrow \mathbf{4 0 \%}$ & $\uparrow \mathbf{1 3 3 \%}$ \\
\hline 8 & 5.3 & 1.53 & $\downarrow \mathbf{3 5 \%}$ & $\uparrow \mathbf{1 5 0 \%}$ \\
\hline 10 & 5.8 & 1.67 & $\downarrow \mathbf{2 9 \%}$ & $\uparrow \mathbf{1 7 4 \%}$ \\
\hline
\end{tabular}

* The uncertainty of the measured physical quantities included in Table 3 was estimated according to the $0.1 \%$ accuracy class of the measuring device (adhesion breaking force). 
for the 4-minute contact time (an improvement of 66\% in relation to the base value was achieved when pumping the liquid for 4 minutes and an improvement of $133 \%$ was achieved for a 6-minute time of contact of the preflush fluid). When analysing the results of the study, an improvement in the adhesion of the cement sheath to the rock was observed to occur in proportion to the increase in the pumping time of the preflush fluid. However, it should be borne in mind that maintaining a too long preflush fluid contact time when washing the annular space may result in flushing out weakly consolidated structures. Therefore, it is very important to choose the correct composition of the preflush fluid, which will enable the removal of the filter cake while maintaining the optimal pumping time and flow rate, ensuring the required tightness on the contact between the casing, the bound cement and the rock formation.

On the basis of the performed research, it was found that the increase in the contact time of the preflush fluid with the rock formation had a positive influence on the effectiveness of the removal of the filter cake. Such an effect was observed during the tests conducted for the filter cake formed from a polymer-potassium drilling mud. However, it is necessary to take into account the diversification of the resulting filter cakes, which depends on the type of the drilled rock formation, the type and parameters of the drilling mud and the borehole conditions (temperature and pressure), therefore each borehole should be considered individually.

\section{Conclusions}

The following conclusions were drawn from the analysis of the influence of the contact time of the preflush fluid with the filter cake on the effectiveness of the annular space cleaning:

1. The tests of the effectiveness of the filter cake removal performed in the laboratory conditions do not reflect the actual condition in the borehole but the designed drilling fluid flow simulator enabled the simulation of semi-borehole conditions.

2. The effectiveness of the filter cake removal depends on the contact time of this fluid and the surface being cleaned.

3. The effectiveness of the removal of the filter cake from the annular space is also determined by the preflush fluid pumping regime.

4. Despite resulting in an improvement in the effectiveness of the removal of the filter cake, the increase in the contact time of the preflush fluid and the rock formation may result in flushing out weakly consolidated zones. Therefore, the pumping time and rate set for a given borehole should not be exceeded.

5. The applied preflush fluid pumping time interval made it possible to obtain adhesion values ranging from 1.01 $\mathrm{MPa}$ to $1.67 \mathrm{MPa}$ (with the value of the adhesion for the specimen with the filter cake being $0.61 \mathrm{MPa}$ and the adhesion of the specimen without the filter cake being equal to $2.37 \mathrm{MPa}$ ).

6 . The obtained results allow us to conclude that the effectiveness of the removal of the filter cake from the polymerpotassium drilling mud was between $66 \%$ and $174 \%$ of the base value.

Please cite as: Nafta-Gaz 2018, no. 1, pp. 29-36, DOI: 10.18668/NG.2018.01.03

Article contributed to the Editor 7.11.2017. Approved for publication 1.12.2017.

The article was written on the basis of a research work entitled: Analiza możliwości poprawy oczyszczenia przestrzeni pierścieniowej otworu wiertniczego przed zabiegiem cementowania - INiG - PIB work commissioned by the Ministry of Science and Higher Education; order no.: 58/KW/17, archival number: DK-4100/58/17.

\section{Literature}

[1] Błaż S.: Nowe rodzaje cieczy przemywajacych osady z płuczki inwersyjnej przed zabiegiem cementowania otworów wiertniczych. Nafta Gaz 2017, no. 5, pp. 302-311, DOI: 10.18668/ NG.2017.05.02.

[2] Habrat S., Raczkowski J., Zawada S.: Technika i technologia cementowań w wiertnictwie. Wydawnictwo Geologiczne, Warszawa 1980 .

[3] Herman Z.: Doskonalenie procesu cementowania rur oktadzinowych $w$ otworach wierconych przy uzyciu pluczek: polimerowej z inhibitorem i polimerowej z inhibitorem kapsutujacym w wybranych rejonach Karpat i przedgórza Karpat. Etap 01 - Opracowanie receptur zaczynów cementowych i technologii cementowania kolumn rur okładzinowych $w$ wytypowanych rejonach wierceń w Karpatach Wschodnich. Unpublished INiG paper, 1995.
[4] Herman Z.: Doskonalenie procesu cementowania rur okładzinowych $w$ otworach wierconych przy uzyciu ptuczek: polimerowej z inhibitorem i polimerowej z inhibitorem kapsułujacym $w$ wybranych rejonach przedgórza Karpat. Etap 02 - Opracowanie receptur zaczynów cementowych i technologii cementowania dla wybranych rejonów skał zbiornikowych przedgórza Karpat. Unpublished INiG paper, 1995.

[5] Jasiński B.: Ocena wplywu cieczy przemywającej na jakość zacementowania rur $w$ otworze wiertniczym po użyciu pluczki glikolowo-potasowej. Nafta-Gaz 2016, no. 6, pp. 413-421, DOI: 10.18668/NG.2016.06.04.

[6] Kremieniewski M.: Ograniczenie ekshalacji gazu w otworach wiertniczych poprzez modyfikacje receptur oraz ksztaltowanie się struktury stwardniałych zaczynów uszczelniajacych. Prace Naukowe INiG - PIB 2016, no. 199, 400 pp. 
[7] Kremieniewski M., Rzepka M.: Przyczyny i skutki przepływu gazu w zacementowanej przestrzeni pierścieniowej otworu wiertniczego oraz metody zapobiegania temu zjawisku. NaftaGaz 2016, no. 9, pp. 722-278, DOI: 10.18668/NG.2016.09.06.

[8] Nelson E.B., et al.: Well Cementing. Schlumberger Educational Service, Houston, Texas, USA, 1990.

[9] Stryczek S., Gonet A.: Kierunki ograniczania migracji gazu z przestrzeni pierścieniowej otworu wiertniczego. WUG: Bezpieczeństwo Pracy i Ochrona Środowiska w Górnictwie, 2005, no. 3, pp. 10-13.

[10] Studia nad doborem zaczynów uszczelniajacych $w$ warunkach wierceń w basenie pomorskim. Praca zbiorowa pod red. S. Stryczka. Prace AGH, Kraków 2016.

[11] Uliasz M.: Kompleksowa analiza przyczyn migracji gazu $w$ otworach realizowanych na przedgórzu Karpat i w Karpatach pod katem wtaściwości cieczy wiertniczych stosowanych w czasie wiercenia i cementowania kolumn rur okładzinowych. Unpublished INiG paper, 2012.

[12] Uliasz M., Chudoba J., Herman Z.: Ptuczki wiertnicze z inhibitorami polimerowymi i ich oddziaływanie na przewiercane skaty. Prace INiG 2006, no. 139.
[13] Uliasz M., Zima G., Błaż S., Jasiński B.: Ocena właściwości cieczy wiertniczych $w$ aspekcie zapobiegania migracji gazu $w$ otworach na przedgórzu Karpat, Nafta-Gaz 2015, no. 1, pp. 11-17.

[14] Uliasz M., Zima G., Błaż S., Jasiński B.: Systemy pluczek wiertniczych do wiercenia otworów $w$ formacjach tupkowych. Prace Naukowe INiG 2012, „Rzeczpospolita łupkowa” no. 183, pp. 225-241.

[15] Zima G.: Wpływ właściwości płuczek wiertniczych na jakość cementowania w gazonośnych poziomach miocenu. Nafta Gaz 2014, no. 12, pp. 899-907.

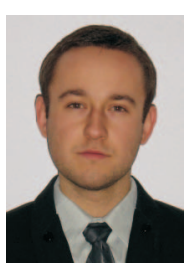

Eng. Marcin KREMIENIEWSKI PhD.

Assistant Professor at the Drilling Technology Department

Oil and Gas Institute - National Research Institute

ul. Lubicz 25 A

31-503 Kraków

E-mail: marcin.kremieniewski@inig.pl

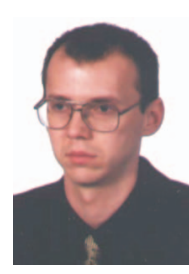

Eng. Marcin RZEPKA PhD.

Head of the Sealant Laboratory at the Drilling

Technology Department

Oil and Gas Institute - National Research Institute

ul. Lubicz 25 A

31-503 Kraków

E-mail:marcin.rzepka@inig.pl

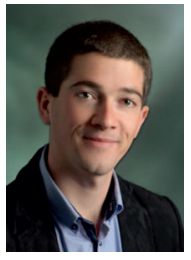

Miłosz KĘDZIERSKI MSc.

Engineering and Technical specialist at the Drilling Technology Department

Oil and Gas Institute - National Research Institute ul. Lubicz 25 A

31-503 Kraków

E-mail: milosz.kedzierski@inig.pl

\section{OFERTA}

\section{ZAKŁAD TECHNOLOGII WIERCENIA}

Zakres działania:

- opracowywanie składów i technologii sporządzania płuczek wiertniczych, cieczy do dowiercania, opróbowania i rekonstrukcji odwiertów, zaczynów cementowych i mieszanin wiążących dla różnych warunków geologiczno-technicznych wiercenia;

- $\quad$ kompleksowe badania i ocena nowych rodzajów środków chemicznych, materiałów płuczkowych i wiążących, przeznaczonych do sporządzania i regulowania właściwości płuczek wiertniczych i zaczynów cementowych;

- $\quad$ pomiary parametrów technologicznych cieczy wiertniczych i kamienia cementowego w warunkach normalnej i wysokiej temperatury oraz ciśnienia;

- badania wpływu płuczek wiertniczych na przewiercane skały;

- dobór płuczek wiertniczych, zaczynów cementowych, cieczy buforowych w celu poprawy skuteczności cementowania otworów wiertniczych;

- badania serwisowe dla bieżących zabiegów cementowania;

- $\quad$ specjalistyczne badania laboratoryjne dotyczace oznaczania: współczynnika tarcia cieczy wiert-

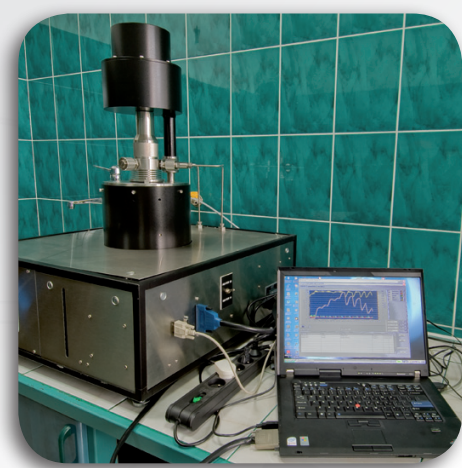
niczych i napięcia powierzchniowego na granicy faz, czystości i temperatury krystalizacji solanek, typu emulsji, sedymentacji fazy stałej, efektywności wynoszenia zwiercin w otworach kierunkowych i poziomych oraz wypłukiwania osadów iłowych ze skał przed zabiegiem cementowania, odporności na migrację gazu w wiążącym zaczynie cementowym w warunkach otworopodobnych, wczesnej wytrzymałości na ściskanie kamienia cementowego, odporności korozyjnej kamienia cementowego w różnym środowisku złożowym, porowatości oraz przepuszczalności dla gazu kamienia cementowego i skał, zawartości związków chemicznych w cieczach wiertniczych, stopnia toksyczności środków chemicznych i cieczy wiertniczych przy użyciu bakterii bioindykatorów;

- $\quad$ badania właściwości fizyczno-mechanicznych skał pod kątem ich zwiercalności.

Kierownik: dr inż. Małgorzata Uliasz Adres: ul. Armii Krajowej 3, 38-400 Krosno

Telefon: 134368941 w. 5219

Faks: 134367971

E-mail: malgorzata.uliasz@inig.pl 